\title{
Article \\ Challenges, Open Innovation, and Engagement Theory at Craft SMEs: Evidence from Indonesian Batik
}

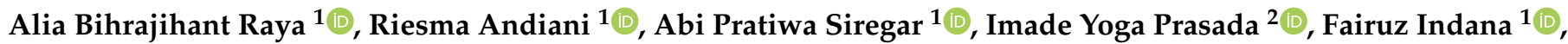 \\ Theresia Gracia Yunindi Simbolon ${ }^{1}$ (D), Agustina Tri Kinasih ${ }^{1}$ (D) and Agus Dwi Nugroho $1, * \mathbb{D}$ \\ 1 Department of Agricultural Socio-Economics, Faculty of Agriculture, Universitas Gadjah Mada, \\ Yogyakarta 55281, Indonesia; alia.bihrajihant.r@ugm.ac.id (A.B.R.); riesma.andiani@ugm.ac.id (R.A.); \\ abipratiwasiregar@ugm.ac.id (A.P.S.); fairuz.indana@mail.ugm.ac.id (F.I.); \\ theresia.gracia@mail.ugm.ac.id (T.G.Y.S.); agustina.tri.k@mail.ugm.ac.id (A.T.K.) \\ 2 Study Program of Agribusiness, Faculty of Science and Technology, Universitas Putra Bangsa, \\ Kebumen 54361, Indonesia; i.made.yoga@mail.ugm.ac.id \\ * Correspondence: agus.dwi.n@mail.ugm.ac.id
}

Citation: Raya, A.B.; Andiani, R.; Siregar, A.P.; Prasada, I.Y.; Indana, F.; Simbolon, T.G.Y.; Kinasih, A.T.; Nugroho, A.D. Challenges, Open Innovation, and Engagement Theory at Craft SMEs: Evidence from

Indonesian Batik. J. Open Innov.

Technol. Mark. Complex. 2021, 7, 121. https://doi.org10.3390/joitmc7020121

Received: 23 March 2021

Accepted: 20 April 2021

Published: 28 April 2021

Publisher's Note: MDPI stays neutral with regard to jurisdictional claims in published maps and institutional affiliations.

Copyright: (c) 2021 by the authors. Licensee MDPI, Basel, Switzerland. This article is an open access article distributed under the terms and conditions of the Creative Commons Attribution (CC BY) license (https:// creativecommons.org/licenses/by/ $4.0 /)$.

\begin{abstract}
Indonesian batik small and medium enterprises (SMEs) are rapidly growing, but they face many challenges in developing their business. For this reason, we propose a combination of open innovation and engagement theory to overcome these challenges. We conducted interviews with 27 local government officers (external stakeholder) and 57 managers of batik SMEs (internal stakeholder). We confirmed the interview results with 20 batik experts and representatives from the Indonesian Ministry of Industry in the Focus Group Discussion. We have divided the findings of this study into two categories: Java and outside of Java, since the two areas have different characteristics. According to our findings, the biggest challenge of batik SMEs in Java is the emergence of the batik printing business. Meanwhile, batik SMEs outside of Java are having difficulty obtaining raw materials. Open innovation has been implemented by some batik SMEs in Indonesia and can improve their business performance. However, more batik SMEs do not implement open innovation due to the lack of their skills and involvement of other stakeholders. As a result, we suggest that open innovation in the Indonesian batik industry needs to be supported by the participation of various parties or that open innovation is combined with engagement theory.
\end{abstract}

Keywords: challenges; open innovation; performance; participation; stakeholders

\section{Introduction}

Small and Medium Enterprises (SMEs) loans in developing countries constitute only $3 \%$ of GDP. This is also experienced by Indonesian SMEs where the amount of lending is one of the lowest globally. However, Indonesia has one of the highest turnovers of SMEs in the world out of all developing countries [1]. SMEs have an imperative role to play in supporting Indonesian economic development [2], due to the large number of SMEs in Indonesia, namely 64,194,000 units in 2018 [3].

Limited funding is not the only barrier to developing SMEs in Indonesia. Budhi et al. [2] stated some other barriers-both internal and external. The internal barriers include low institutional and human resources, slow technology adoption, and marketing difficulties. Meanwhile, the external barriers consist of high production and distribution costs and inefficient bureaucratic services. Moreover, the Indonesian government policies are still not optimal for helping the development of SMEs. Mass media support for the development of SMEs in Indonesia is also lacking. All the published articles are only fulfilled by the role of the government and the private sector [4].

This phenomenon is certainly interesting to learn how SMEs in Indonesia can survive in the face of multiple challenges. However, as researchers, it is difficult for us to observe all SMEs in Indonesia. We are focused only on sectors with fast-growing SMEs. Wijaya and 
Suasih [5] stated that SMEs in Indonesia which are growing rapidly are creative industries, mainly craft SMEs. The Indonesian Ministry of Trade [6] noted that one of the high-value SMEs craft products is batik. This product has become a national icon and has been exported to various developed countries, including the United States, Singapore, Canada, Australia, and Spain. By 2020, the export value could reach 21.5 million US dollars.

The Indonesian batik was added to UNESCO's Intangible Cultural Heritage of Humanity list in 2009. It has been internationally recognized as the historical fabric of human civilization. Batik is often used as a general term for the fabric dyeing process. The process is traditionally performed on cotton and silk using a resist technique. Other batik techniques, such as hand-painting methods, the splash method, and the screen-printing process [7].

Although it appears that Indonesian batik SMEs are very advanced, they face numerous challenges in developing their business. Moreover, market and technology dynamics are increasing every time. Indonesian batik SMEs must know their challenges and adopt open innovation to improve their performance and competitive advantage [8,9]. Yun et al. [10] stated that open innovation has a definition where an organization relies not only on its technology to innovate but also on external knowledge and other technologies (such as user innovation, customer innovation, collective intelligence, crowdsourcing, etc.). According to the theory's creator, Chesbrough [11], open innovation shows how a company can use its business model to find a more enlightened role for R\&D in a world of abundant information, better manage and access the intellectual property, advance its current business, and develop its future business.

Open innovation grows with the technology openness strategy of firms, complex adaptive systems, and market responses stimulated by technology innovations. Firms are the primary actors that drive such evolution in the market as essential autonomous agents in the overall innovation system. The period of significant open innovation situation usually occurs in the early stages of the industry. It then decreases when the industry has matured. In this condition, technology among companies does not significantly differ, and price competition is more important. Companies that continue to do open innovation will get meaningful results, especially dominating the market [10].

However, this is not as easy as imagined since many batik SMEs are conservative and reject innovations. Moreover, we have found that batik SMEs cannot improve their business performance if they do not implement open innovation properly [12]. This condition because of many surrounding conditions in the market, technology, regulations, and the lack of participation of stakeholders $[10,13]$. Therefore, in this study, we combine open innovation with engagement theory. Engagement theory is presented as a model for learning in technology-based environments. The first principle of this theory is "Relate" where SMEs must work together to improve communication, planning, management, and social skills to face various challenges. The following principle is "Create" where SMEs are expected to identify the challenges and focus their efforts on applying ideas to solve them. The last principle is "Donate" which stresses that SMEs must provide value or contributions to outsiders, especially customers [14].

As stated by Kearsley and Shneiderman [14], the engagement theory is used for education, but we believe that it can be used to strengthen the implementation of open innovation in SMEs. Our courage in combining the two theories is based on West et al. [15], which mentioned that there would be increased integration of open innovation with a well-established theory of innovation, management, and economy in the future. This combination has also been proven in the literature that applies engagement theory to various businesses $[16,17]$. This means that open innovation is quite possibly combined with engagement theory.

Open innovation and engagement theory have mutually supportive relationships. Grama-Vigouroux et al. [18] stated that stakeholder participation would switch firms activities and strategies from closed to open innovation. Meanwhile, Deltour [9] stated that strong ties between business groups do not guarantee their open innovation or partnership 
involvement. When combined with a stakeholder-driven engagement process, the open innovation concept offers solutions for all actors participating in the business innovation process, from research to intermediaries up to industrial implementation $[19,20]$. Mawson and Brown [21] claimed that open innovation might also create close stakeholder engagement.

Multiple studies have combined these two theories, for example, in the digital [13], high-tech manufacturing [19], education [22], and health sector [23]. However, until now, no one has yet combined the two theories in the craft industry. Moreover, this industry has unique characteristics, such as traditional, hand-made, prioritizing art, and necessitating caution in implementing these two theories.

We believe that this study will have many benefits and lessons for developing the crafts and arts SMEs in other countries. This is due: First, batik is a craft that UNESCO has recognized as a world heritage. So, it can be an excellent example for the development of SMEs or companies that focus on various crafts and arts. Also, batik has been marketed globally. However, there is a possibility that consumers will quickly get bored by using batik because the motif is very traditional. Second, even though it is a craft, the physical form of batik is fabric or clothes. There have been many clothing factories with strong economies of scale in Indonesia and around the world. This condition made the competition for clothes sales increasingly competitive and made it possible for batik SMEs to go bankrupt. Last, Indonesia is a country with a large population and ethnically diverse. This makes Indonesia a good "raw model" since population conditions are complex and represent consumers with many preferences. Moreover, the vast territory of Indonesia and unequal development between regions may make it difficult for SMEs related to the distribution of raw materials and their output and the diversity of challenges faced by SMEs.

Based on the various conditions and theories that we have previously disclosed, our study questions are as follows:

SQ1: What are the challenges faced by Batik SMEs in Indonesia?

SQ2: Does open innovation helps to improve the performance of Batik SMEs in Indonesia?

So, the aims of this study know the challenge faced by batik SMEs in Indonesia and determining whether or not open innovation help to improve the performance of these SMEs. The results of our study will make a significant contribution to the development of craft SMEs in Indonesia and around the world. Our research will describe the various challenges faced by these SMEs. We also identify various open innovations carried out by batik SMEs in Indonesia to help overcome the challenges of other craft SMEs and develop their business. The combination of open innovation and engagement theory will strengthen our research to encourage each stakeholder in the craft industry, to understand their respective roles and functions, especially in helping craft SMEs overcome challenges and develop innovations. This will also allow researchers to combine open innovation with various theories to improve its effectiveness.

After the introduction, this article presents a literature review of the challenge of craft SMEs and the SMEs culture for open innovation (Sections 2.1 and 2.2). The reader can find the theoretical framework of this study in Section 2.3. Next, Section 3 describes the location, data collection procedure, and methodological framework. Results and Discussion are presented in Sections 4 and 5. Conclusions, Implications, Limitations, and Future Research are presented in Section 6.

\section{Literature Review and Theoretical Framework}

\subsection{The Challenge of Craft SMEs}

The first challenge for craft SMEs is increased production costs. As a result, SMEs will face financial instability and lower profits [24]. Craft SMEs have difficulty searching bank loans because of their low small economies of scale and profitability [25]. Even though access to financial institutions is vital for craft SMEs to improve their innovation and competitiveness [26]. Funds can also be critical for craft SMEs to obtain access to the required resources [27]. According to Agyapong [28], financial risks force SMEs to be more creative and innovative in their processes and procedures, resulting in increased efficiency. 
The quality of human resources (HR) is the next challenge for craft SMEs. Improving HR quality is very important for SMEs to improve their market orientation and business performance [29]. Moreover, the craft business is unique because the employee must have special skills and a high level of creativity [30]. Unfortunately, some SMEs have not prioritized employee skills growth. SMEs must provide training or internships, especially for new and inexperienced employees [31]. Another thing is SMEs' ability to build partnerships with suppliers is still limited. This will create ways for SMEs to market their products at more affordable prices and improve their performance [32,33].

Aside from quality, another HR challenge is employee regeneration. Today, young people are reluctant to learn craft skills and prefer to work in other fields. This put the craft business at risk due to the loss of its future successors [34]. Also, craft SMEs are managed by the elderly will be slow to grow. They prefer to be conservative by refusing the entry of open innovation and keeping the uniqueness of traditional designs. As a result, craft SMEs are slow in adapting to the ever-changing trends in the global market [33].

Another challenge is the lack of a proper sales and marketing strategy. Changing consumer behavior is the most challenging for craft SMEs. Consumers are always looking for the latest trends. Meanwhile, SMEs' design abilities are still lacking. They design products using traditional knowledge and lack access to modern product design skills or techniques [34]. This is important because craft SMEs must compete with other SMEs or big capital firms that produce similar products [35].

Today's marketing challenges are also increasing along with technological advancements. Consumers prefer to find products through digital media [36,37]. However, SMEs have not optimally carried out advertising and marketing strategies or have grasped or used online marketplaces and promotions [34]. Even many craft SMEs have used digital media, but they have not used it effectively [38]. This has an impact on the inability to produce unique, varied, and high-quality products. Furthermore, a lack of technological capabilities also results in ineffective and inefficient work processes [39].

Meanwhile, the supporting industries do not always contribute optimally to the development of craft SMEs. Even though many industries can synergize with craft SMEs, for example, the tourism industry can design a marketing location or SMEs shop as a tourist destination. If the synergy between SMEs and supporting industries works well, it will help develop the regional economy [30].

\subsection{The SMEs Culture for Open Innovation}

Open innovation must be a culture in a business organization. Open innovation can be done by encouraging collaboration, sharing knowledge, experiences and ideas among the organization members [33]. Mawson and Brown and Prasanna et al. [21,40] stated that to compete in today's fierce business environment and global competition, SMEs must practice open innovation. SMEs which implement open innovation have a high-risk tolerance, a desire for close customer interaction, effective business models, and a strong external focus. Sasaki et al. [41] claimed that open innovation should be a business culture and the readiness of a business to do new things at different times and markets. Differences in geographic markets, customer segments, or new product/market segments will all necessitate strategic innovation.

Open innovation continues to be carried out by SMEs in production activities. SMEs use machinery or technology to increase efficiency. They can also innovate by developing new products and methods and exploring various raw materials [36]. Production factors and energies are used to a minimum and, if possible, can be used for other business operations (reuse or recycling of wastes). Apart from saving costs, this step is also taken to ensure the sustainability of business and the environment. There are also SMEs that use natural raw materials as a substitute for chemicals [42].

In terms of marketing, SMEs engage in open innovation such as diversification and creativity of products and services, excellent service and quick response, good communication with consumers, convenient facilities and entertainment for customers, and set up 
platforms to promote products [43]. Even to reach into international markets, SMEs must take the risk of recruiting foreign experts. This is done to connect the characteristics of domestic products with the desires of international customers [41]. It aims to offer the best prices for consumers, increase consumer loyalty, and increase the productivity of marketing activities [44].

As part of the 4.0 Industrial Revolution, SMEs are starting to use digital media to support their business goals and activities. This has the potential to improve the company's performance. Digital media positively impacts SMEs by reducing communication and promotion costs, increasing sales volume, simplifying information delivery, and improving relationships with customers and stakeholders [38].

The way to achieve excellent innovation results in their performance is SMEs should develop solid and appropriate strategies to encourage employees to be creative at all times. This is generally referred to as organizational culture to innovate. This will appear if the company is led by someone who has a broad vision and can convey it to employees. Leaders will encourage employee collaboration while also giving them the freedom to innovate. The company is also directed to consistently create, communicate, and provide value to customers and give them the best service [45-47].

Sometimes open innovation at SMEs cannot always stand alone. This must be combined with other factors, such as entrepreneurship. The promotion of entrepreneurship is required first before investigating the open innovation strategies of SMEs. As a result, entrepreneurship was proven to successfully realize open innovation and become an essential strategy for SMEs focusing on rapid international expansion [21,48,49]. Therefore, we combine open innovation with other factors in our research, namely engagement theory.

\subsection{Theoretical Framework}

Based on the stakeholder's theory of the modern corporation by Freeman [50], the industry consists of internal and external stakeholders. Owners, managers, and employees are internal stakeholders, while suppliers, customers, and the local community are external stakeholders. The owner provides capital to the company, whether it be money, stocks or bonds, and expects some financial return. Managers and employees will dedicate their time, resources, and lives to the firm. They will get wages, benefits, and security from the firm based on their skills and contributions. Firms must maintain good relationships with external stakeholders. First, suppliers facilitate the supply of raw materials, and their role is very vital in product quality and price. Second, customers will buy products from the firm and have an indirect role in developing products and services. The last external stakeholder is the local community, which gives the company the right to construct facilities. They will also benefit from tax paid by the company. All of these stakeholders will be involved in developing the craft industry, as seen in Figure 1.

However, in Figure 1 we also add to the role of open innovation and engagement theories to facilitate business in the craft industry. Open innovation is always required to ensure the industry competitive and profitable for all participants $[8,21,43,44]$. We have found that the implementation of open innovation can improve the business performance of a firm [48]. But, the multiple challenges faced by craft SMEs will be hampered their business performance. This becomes a gap and encourages us to carry out this study (research gap).

Moreover, open innovation is influenced by many surrounding conditions in the market, technology, regulations, and the lack of stakeholders participation [10]. For this reason, we added engagement theory to the craft industry. Therefore, the novelty of this research is we combine open innovation with engagement theory to solve the described problems in craft SMEs.

In Section 2.1, we have presented numerous challenges faced by craft SMEs. These challenges include the supply of production, marketing, and supporting (finance) subsystems. As a result, craft SMEs are unable to reach optimal performance. While in Section 2.2, we demonstrate that open innovation helps improve SMEs' performance in different in- 
dustries. This effect has been proven to encourage SMEs to produce competitive products, increase turnover, establish good relationships with consumers and others.

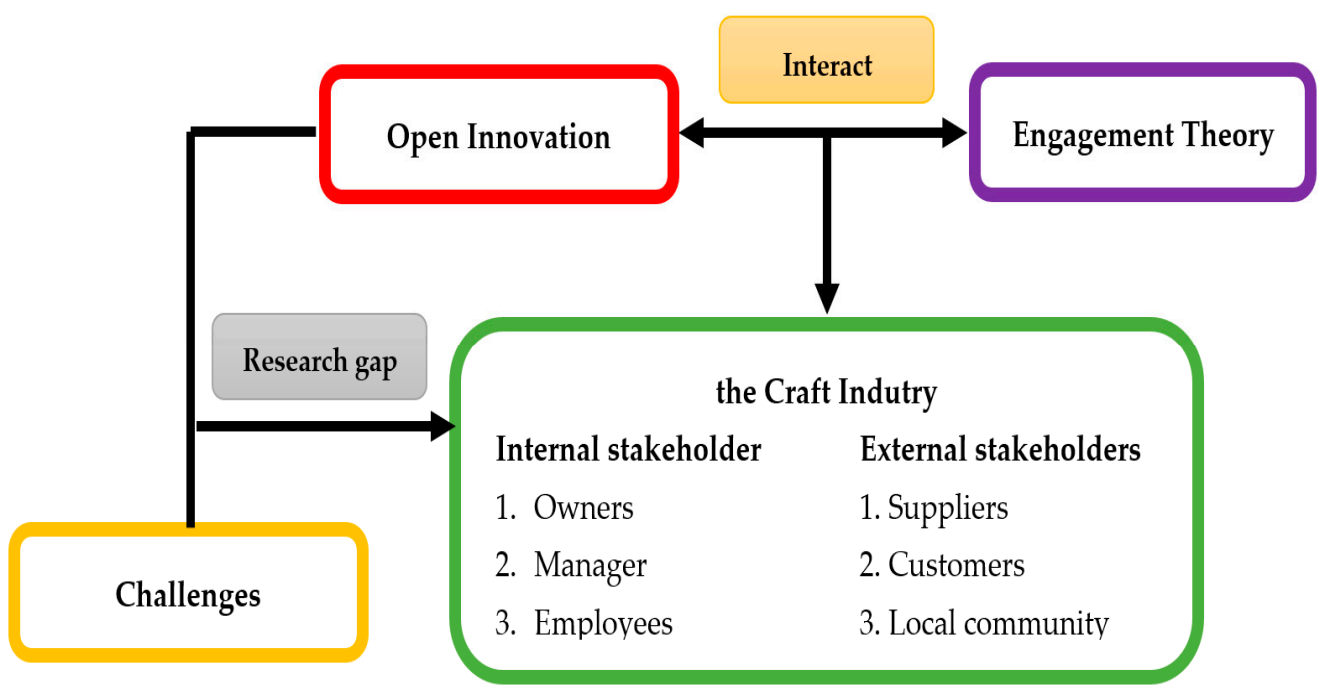

Figure 1. The theoretical framework of this study.

\section{Materials and Methods}

\subsection{Location}

Purposive sampling was used to identify the study area based on the Indonesian Ministry of Industry [51] about Indonesian batik-producing provinces. According to these data, there are 27 provinces in Indonesia that produce batik, namely Aceh, North Sumatra, West Sumatra, Riau, Riau Islands, Jambi, Bengkulu, South Sumatra, Bangka Belitung Islands, Lampung, Banten, West Java, Special Capital Region of Jakarta, Central Java, Special Region of Yogyakarta, East Java, Bali, West Nusa Tenggara, North Kalimantan, Central Kalimantan, East Kalimantan, North Sulawesi, Central Sulawesi, South Sulawesi, North Maluku, Maluku, and Papua. Meanwhile, 7 provinces were left out of this study because they did not produce batik.

We grouped the analytical results in this study into two categories: batik SMEs in Java Island and batik SMEs outside of Java. This is due to variations in characteristics between the two categories. This is also based on Maulana et al. [44], who stated that the regional topography influences the differences in the characteristics of SMEs in Indonesia. The other reasons are: First, according to data from the Indonesian Ministry of Industry [51], the batik production centers and SMEs are located in Java. This will impact the differences in raw materials, production facilities, and challenges between the two categories. Second, differences in the economic and infrastructure conditions of the two categories may impact the types of challenges faced in each region [52]. Third, batik is always synonymous with Java, allowing for differences in consumer perceptions between the two categories and creating challenges for batik SMEs in the marketing subsystem $[27,35]$.

\subsection{Data Collection Procedure}

This research was conducted for 3 (three) months from October 2019 to December 2019. Primary and secondary data were used for the study. There were two main stages in the data collection. The first stage began with the process of identifying the challenges of batik SMEs at a macro level. Therefore, it is started by conducting unstructured depth-exploratory interviews with the local government officers in each Indonesian batikproducing province. They become representatives of external stakeholders. We interviewed 1 officer in charge of developing batik SMEs in the province. So, we interviewed 27 peoples, namely 6 officers in Java and 21 officers outside of Java. The questions were about the challenges faced by batik SMEs in production, marketing, and supporting (finance) 
subsystems in each province and the efforts to solve them (Table 1). Local government officers will talk about all of these challenges, and we are starting to take note of them.

Table 1. Research questions to the local government officers.

\begin{tabular}{cc}
\hline Number & Question \\
\hline 1. & What are the challenges faced by batik SMEs in your province? \\
\hline 2. & What are the efforts of the local government officers to solve these challenges? \\
\hline
\end{tabular}

In the first stage, a discussion was held with the local government officers to develop a list of batik SMEs to be interviewed. Then, it is decided to interview some best batik SMEs in each province because they are on the board of the batik association in their region and usually intimately familiar with the challenges of the batik industry. Also, information about the innovations that they created to help them succeed in the batik industry can be earned. We selected 3 SMEs in the central batik-producing provinces in Indonesia, namely West Java, Central Java, Yogyakarta Special Region and East Java. Whereas in other provinces, picked 2 SMEs.

For the second stage, unstructured depth exploratory interviews with the top 2-3 batik SMEs in each province were conducted. As a result, we interviewed was 57 batik SMEs managers as representatives of internal stakeholders. The information gained from them was about the challenges of the batik industry, the efforts to solve them, and the innovation created by batik SMEs in their region (Table 2). We also spent time at their business place, which allowed us to observe how they operate and the latest innovation developed together with their partners.

Table 2. Research questions to batik SMEs.

\begin{tabular}{cc}
\hline Number & Question \\
\hline 1. & What are the challenges faced by your business and another batik SMEs in your \\
province?
\end{tabular}

Then, we confirmed the interview results again with batik experts in Indonesia and representatives from the Ministry of Industry. We try to get various additional information from these stakeholders through forums group discussions (FGD). The FGD was attended by 20 peoples from these two stakeholder groups.

The total sample of respondents for this study was 104 peoples, made up of 27 local government officers, 57 managers of batik SMEs, and 20 batik experts and representatives from the Ministry of Industry. According to Hair Jr et al. [53], the minimum number of samples in a study should be 100 . Thus, the number of samples in this study has also met the requirement and is suitable for analysis.

\subsection{Data Analysis}

In this study, the analysis began with examining data extracted from the interviews. Then, an analysis of vertical interview-by-interview was conducted to discover what each local government officers answered about the challenges in the production, marketing, and supporting (finance) subsystems of the batik industry in their provinces. The analysis result of this interview is shown in the form of a percentage diagram in Section 4. The same analysis technique was used for answered from SMEs. However, a descriptive analysis was added to deepen their answers about the causes and impacts of each challenge faced by SMEs and their open innovation. Sections 5.1 and 5.2 contain the findings of this analysis.

A descriptive or causal analysis was used to ascertain the challenges faced by Indonesian batik SMEs and the impact of open innovation on their performance. The main 
characteristic of this analysis is that the researcher does not have control over the variables and can only focus on what has happened or is happening. Also, accuracy is a significant consideration and research designs that minimize bias and maximize the reliability of evidence gathered are considered good designs [54]. Quantitative and qualitative data can be used for this analysis. Quantitative data such as frequency, or mean and standard deviation, are essential for descriptive studies. Meanwhile, qualitative data will help interpret phenomena during the study's exploration stage [55].

Descriptive or causal analysis can be used to understand "why" a situation has a causal effect. An excellent causal analysis can assess the effects of a situation and effectively describe population characteristics, implementation features, and the nature of the setting that are most relevant to interpreting the findings [56,57]. In addition, this analysis helps the researcher think systematically about aspects of a particular situation, offers ideas for further investigation by more analytical perspectives and correlations, and helps make certain simple decisions [55,58].

Descriptive analysis is carried out by exploring frequencies, averages, and other statistical calculations about certain phenomena. Researchers must use current evidence or information and analyze this to allow a critical evaluation of the material. Although this analysis was very accurate, but it could not completely gather the causes behind the situation [59]. But this analysis can provide many benefits include the fact that it can be done quite quickly and easily, the researcher is easy to allocate resources, and provides the first important clues regarding the possible determinants of a phenomenon [60]

Finally, we will also describe the results of the FGD to reinforce the findings of the interviews with the local government and batik SMEs.

\section{Results}

\subsection{Challenges in the Production Subsystem}

\subsubsection{Java}

As many as $83.33 \%$ of local government officers in Java stated that batik SMEs face challenges in the production subsystem (see Figure 2). They claimed that these challenges included the low quality of raw materials, a lack of employee skills, and less professional business management. Meanwhile, batik SMEs revealed another challenge was the increase in raw material prices, especially batik colors, and that there was no regeneration process for batik employees.

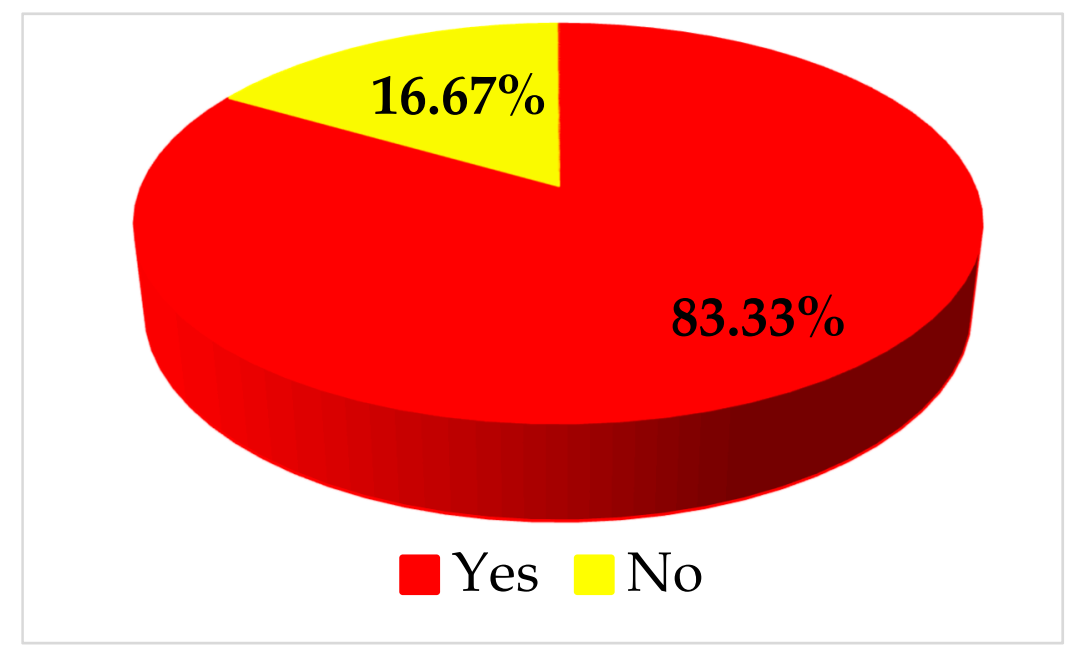

Figure 2. Challenges of batik SMEs in Java on the production subsystem.

\subsubsection{Outside of Java}

Local government officers outside of Java noted that SMEs in their region face challenges in the production subsystem (see Figure 3). Some of these challenges include 
difficulties in obtaining equipment and raw materials, limited employee skills, and poor business management. Batik SMEs also stated that they needed to buy equipments and raw materials from Java. They have difficulties on finding workers, particularly for making batik motifs.

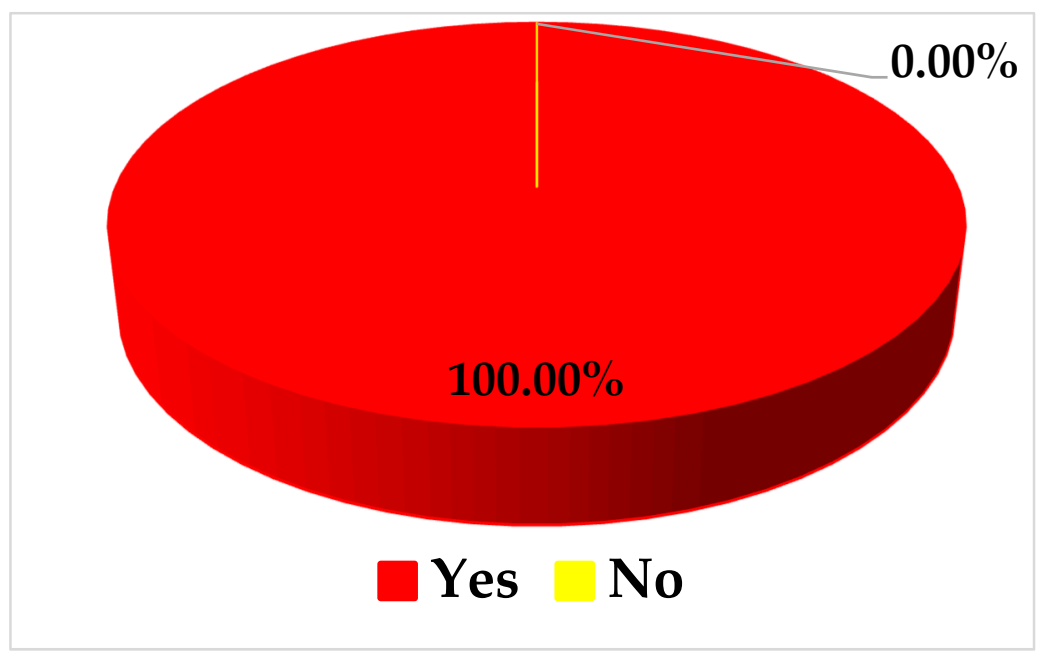

Figure 3. Challenges of batik SMEs in outside of Java on the production subsystem.

\subsection{Challenges in the Marketing Subsystem}

\subsubsection{Java}

Figure 4 shows the challenges of batik SMEs in Java on the marketing subsystem. All local government officers stated that the batik industry in the province faces challenges in the marketing subsystem, namely the emergence of the batik printing business. This was also reinforced by batik SMEs in Java, who reported that the batik printing business had begun to dominate the market. This batik is produced in a factory using a machine and is cheaper than hand-painting batik.

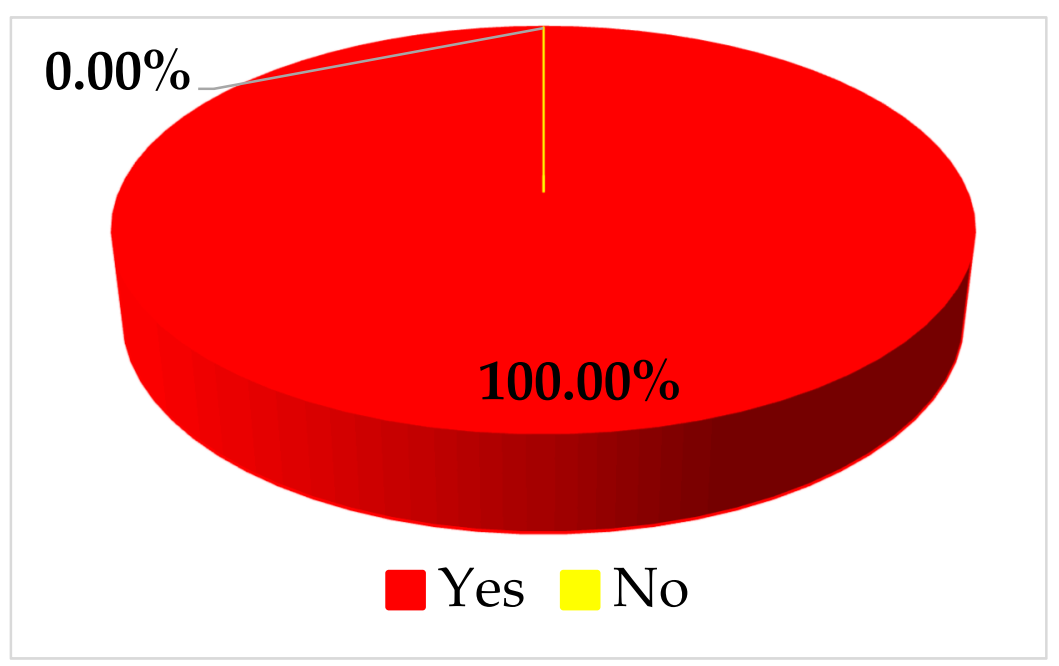

Figure 4. Challenges of batik SMEs in Java on the marketing subsystem.

\subsubsection{Outside of Java}

Almost similar to Java, $90.48 \%$ of all government officers outside of Java indicated that the batik industry in their province was facing challenges in the marketing subsystem (see Figure 5). Batik SMEs said the same thing, namely the emergence of the batik printing business, the reluctance of consumers to buy batik, and rivalry with local fabrics, all of which are challenges to their marketing subsystem. 


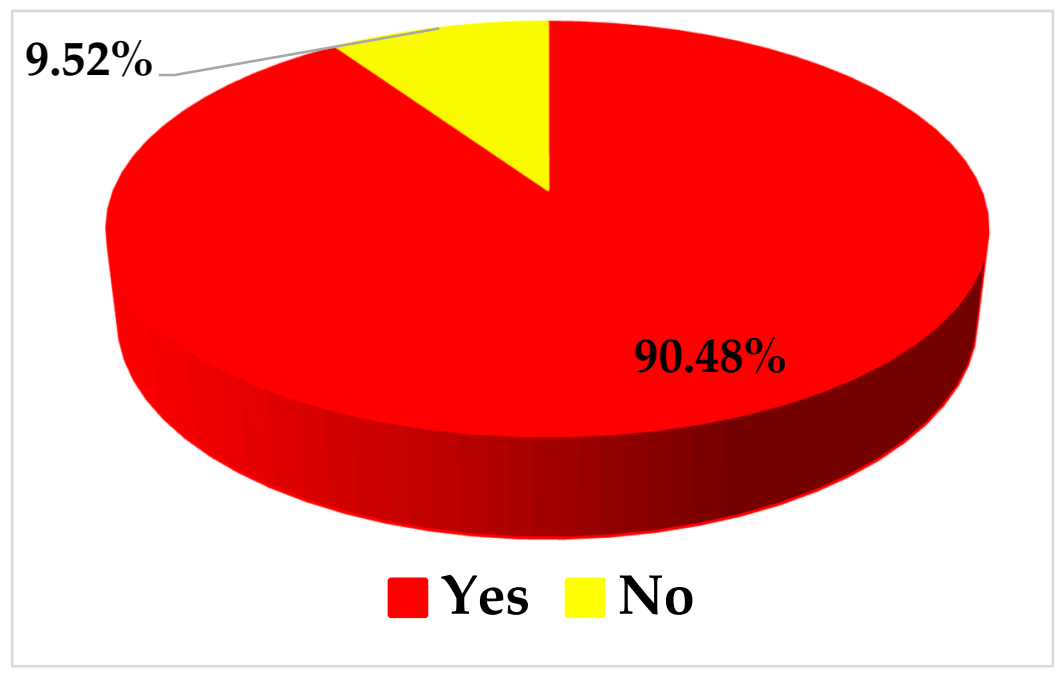

Figure 5. Challenges of batik SMEs in outside of Java on the marketing subsystem.

\subsection{Challenges in the Supporting Subsystem}

4.3.1. Java

Next, the challenges faced by batik SMEs in Java lie in their supporting subsystems (see Figure 6). According to local government officers and batik SMEs, the biggest challenge in this subsystem is the difficulty of batik SMEs in accessing funds or capital from financial institutions.

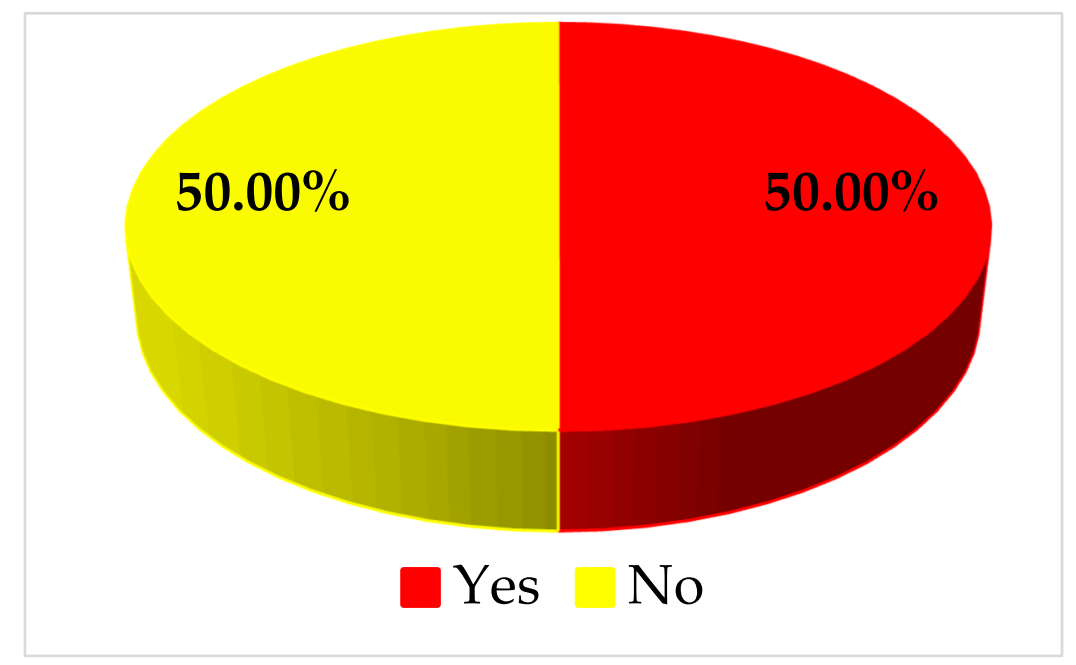

Figure 6. Challenges of batik SMEs in Java on the supporting subsystem.

\subsubsection{Outside of Java}

As many as $76.19 \%$ of local government officers outside of Java stated that the batik industry in their province faces challenges in the supporting subsystem (Figure 7). Following confirmation from batik SMEs, these challenges included difficulties in accessing capital from financial institutions and local government officers have not a complete profile of batik SMEs in their region. 


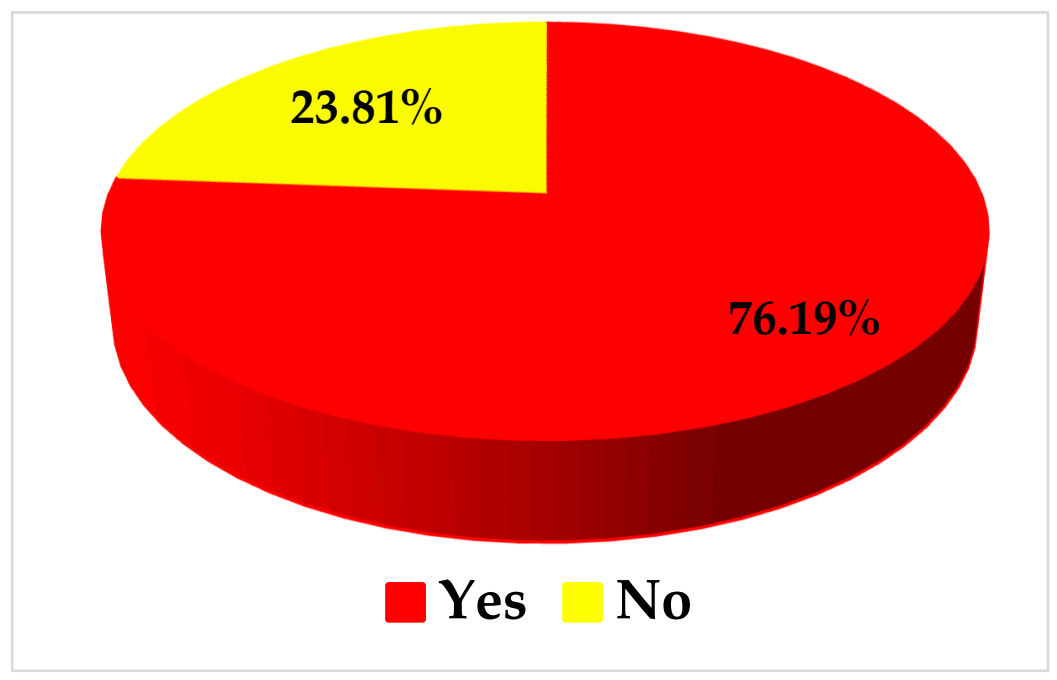

Figure 7. Challenges of batik SMEs outside of Java on the supporting subsystem.

Then, we presented these findings in the FGD, which included batik experts in Indonesia and representatives from the Indonesian Ministry of Industry. They confirmed that all of these challenges existed in the Indonesian batik industry. They stated that the most significant challenge for the Indonesian batik industry was the unavailability of a complete database of Indonesian batik SMEs and the emergence of the batik printing business in the market. Both contribute to the poor performance of batik SMEs. However, we will go through this in more depth in Sections 5.1 and 5.2.

\section{Discussion}

\subsection{The Challenge of Batik SMEs in Indonesia}

\subsubsection{Java}

The challenges faced by batik SMEs in Java in terms of production subsystem are numerous. The first challenge is the rise in raw material prices. In recent years, the price of fabrics and dyes has continued to increase. The rapid growth of the batik industry has increased the demand for raw materials. As a result, raw material stocks could not meet this demand, and prices began to rise. Simultaneously, raw materials such as fabric and dyes are the highest cost in batik production [61]. The increasing price of fabric and dyes has been shown to increase the cost of batik production [62]. Furthermore, this will raise the price of batik and may decrease the competitiveness of batik SMEs.

Until now, batik SMEs have been unable to find a solution to the increase in fabric prices. When a substitute material is not available, batik can only be made with Mori fabric. As for dyes, batik can replace chemicals with natural dyes. These are available in the surrounding area and are cheaper than chemical dyes [62].

The second challenge is a lack of human resource skills. This caused a lot of errors in the batik production process [61]. This is consistent with the results of a study by Wahyuni et al. [35], which finds that the most human error in batik SMEs happens during creating a batik motif, cutting fabric, dyeing cloth, and releasing wax from cloth. Even though the craft business is unique so that the employee must have special skills and a high level of creativity [30]. These skills will have an impact on the quality of the batik produced as well as the time it takes to make batik. It can also cause consumers to become dissatisfied and stop buying batik SMEs products. For example, customers from other countries cancel their purchases because some batik motifs are not the same as those ordered. This difference is due to differences in the batik makers' job skills. Another lack of skills is found in business management. Many SMEs do not have good financial management and business planning skills. This prevents them from innovating in both production technology and market expansion. 
"... we want to exports our products. However, we cannot do it because of the different skills of each employee, resulting in differencing the batik quality and motif. Even though foreign people like similar batik." (Giriloyo Batik SME, Bantul Regency, Special Region of Yogyakarta Province)

This situation is exacerbated by the lack of interest among the young people to inherit the batik crafting skills. The majority of young people choose to work in some big cities or other professions [63]. They believe that the handicraft business is complicated to do because it requires special skills. Meanwhile, the income earned is lower than in most professions. The low skills of employees and the community's reluctance to work in the batik industry have long been a challenge in Java [64].

Furthermore, the challenge in the production subsystem is the chemical dye waste management system that is not running well. Many batik SMEs do not have a waste management system in place. They directly dump the chemical dye waste into the river, causing environmental harm. For e.g., 4 rivers in Pekalongan (Central Java Province) are no longer suitable for agricultural irrigation because they have been polluted by batik waste [64]. Waste management like this could become a problem in the future, particularly if batik SMEs want to export to the developed countries [65]. These countries will pay attention to environmental standards, one of which is the Quality Standard for Textile Effluent set by The World Bank. Even though there is an example of good open innovation for this waste management in Sri Lanka. Woven fabric dye factory waste in this country is processed correctly to meet environmental standards, then treated water is used for agricultural purposes [34]. Several research findings illustrate different methods or materials for batik wastewater treatment [66]. However, this has not been commonly adopted by batik SMEs.

In the marketing subsystem, all local government officers claimed that batik SMEs in Java faced challenges with the emergence of the batik printing business. In addition, the import of batik from other countries increases the competition in the market. This condition disrupted batik SMEs business in Indonesia [67].

"... If the government is serious about protecting batik, they must clearly position the batik printing. Batik SMEs will be unable to compete with the batik printing ..." (Nevil Batik SME, Pekalongan Regency, Central Java Province)

The batik printing is produced by factories using sophisticated machines. They are also produced in large quantities with low production costs and fast uptime. The batik printing is made solely for profit, with no regard for the artistic side of batik work. This contrasts to SMEs, which believe batik is a handicraft created as a work of art. Because of this difference in vision, the batik market has become unbalanced, with the batik printing can dominate the market rather than SMEs' products. Even consumers cannot distinguish between handpainted batik by SMEs and batik printing because they are similar [68]. Finally, consumers prefer batik printing because the price is cheaper and can be continuously available.

"... when we participated in an exhibition in Thailand, the batik printing is available in the in front of us. People who are unfamiliar with batik will choose to buy the batik printing ... " (Quu Batik SME City, Cirebon West Java Province)

Another challenge in the marketing subsystem is the development of digital media. Consumers want to discover anything through digital media, including when searching for batik. However, due to limited human resources, not all batik SMEs use digital media, such as social media or e-commerce, to market their products [69].

Last, the challenge for batik SMEs in Java is the support subsystem. One of the challenges for the development of batik SMEs is a lack of capital. As a result, batik SMEs cannot perform optimally, resulting in lower profits [70-72]. They also have difficulty getting loans from financial institutions, because they do not understand administration and lack collateral following these institution's requirements. 
"... capital is a major problem for batik SMEs in this region ... " (Yandri Haryandi, Pusaka Banten Batik SME, Serang Regency, Banten Province)

\subsubsection{Outside of Java}

The first challenge for batik SMEs outside of Java is the difficulty in obtaining raw materials. This was stated by all local government officers and batik SMEs outside of Java. The center of the raw material industry and others in Indonesia is centered in Java [52]. For example, in one of the batik centers outside of Java, Jambi Province, its SMEs had to bring in raw materials from Central Java and the Special Region of Yogyakarta Provinces. These raw materials include Mori fabric, batik dye, batik wax, canting (a tool for painting batik motifs), and batik stamping tools. This is reinforced by Wahyuni et al. [35] that one of the challenges for batik SMEs outside of Java is the lack of raw materials. The difficulty in obtaining raw materials causing batik SMEs outside of Java delays in their production process and bears high raw material costs. This also makes batik outside of Java expensive and unable to compete with batik made in Java.

"... sometimes it takes a long time to come from Java, so we buy fabric from Ms. T (another batik SME owner). But it's more costly IDR 40 to 50 thousand compared to the fabric from Java ... " (Kampung Batik SME, Bengkulu City, Bengkulu Province)

"... We have to pay a lot of money to buy raw materials from Java. I have to provide funds of about IDR 7 million for shipping costs by ship. If I want it to be delivered quicker, by plane, the costs will be higher ... " (Kustalany, Tubo Batik SME, North Maluku Province)

Batik SMEs outside of Java have attempted to reduce their reliance on raw materials from Java. However, until now, these attempts have not been successful. Batik artisans in Lampung try to use locally purchased fabric, but they produce batik that is unattractive and does not sell well. Finally, they are once again purchasing raw materials from Java. Even many SMEs outside of Java order finished batik from Java. Then, they sell in their respective territories. Production costs in this way were found to be cheaper than if those of SMEs making their batik.

The second challenge is the low skill of the employees. Like the challenges in Java, batik SMEs employees outside of Java find it challenging to create batik motifs [73]. Furthermore, SMEs are also having difficulty finding employees who can and are willing to create batik motifs. This causes the batik motifs and coloring are untidy. Finally, many batik SMEs hired employees from Java. This also causes the slow regeneration of batik artisans outside of Java.

"... we realize that human resources are difficult to develop, so the quality of batik remains poor. We don't have the confidence to wear Lampung batik yet, particularly when compared to the batik from Java ... " (Local Government of Lampung Province)

"... I warn people that in 10 years, batik will no longer exist because there is no successor ... " (Tanah Liek Bundo Kanduang Batik SME, Padang City, West Sumatra Province)

Another human resource challenge is that the managers of batik SMEs lack business management skills. They do not understand to make financial records, neither business revenues nor expenditures. This is very important when SMEs batik wants to apply for a loan from a financial institution. They do not have a plan related to the business growth strategies, both increasing production and expanding the marketing area. Because of this situation, batik SMEs outside of Java are unable to achieve optimal performance.

In the marketing subsystem, batik SMEs outside of Java face competition from the batik printing and local fabrics. When competing with the batik printing business, batik SMEs outside of Java experience the same effect as Javanese batik SMEs, so we will not 
discuss it again. We are more interested in discussing batik competition with various local fabrics outside of Java.

Almost every outside of Java has local fabrics, such as woven fabrics in Southeast Sulawesi Province, Jumputan fabrics in Bali and South Sumatra Province, Cual fabrics in Bangka Belitung Province, and others. These local fabrics have become a characteristic of civilization in each region [74]. As a result, the interest of batik buyers outside of Java is not as strong as buyers in Java.

"... Actually, there are people who buy batik, but only a few and the process takes a long time. Finally, we focused on jumputan (local fabric) ... " (Griya Kain Tuan Kentang Batik SME, Palembang City, South Sumatra Province)

In addition, batik SMEs outside of Java has not yet fully adopted online marketing. They continue to focus on word-of-mouth (WoM) and outlet marketing. This makes their market penetration is limited and sales are modest. This is consistent with Eisingerich et al. [75] findings that delivery of market information via WoM is slower than via digital media.

In terms of the supporting subsystem, batik SMEs outside of Java face two challenges: capital and an incomplete profile database of batik SMEs. Like most other SMEs, batik SMEs outside of Java have difficulty borrowing money from banks because their business is deemed less viable. Until now, they still rely on their capital. However, this results in suboptimal output. Meanwhile, the incomplete profile database of batik SMEs occurred due to the local government officers' difficulties accessing its vast territory. In the end, the local government officers found it difficult to implement policies for the development of batik SMEs, especially in providing equipment, capital, and training assistance. This necessitates the development of an online national database containing profiles of Indonesian batik SMEs.

\subsection{Open Innovation of Batik SMEs in Indonesia}

Batik SMEs face various challenges both in Java and outside of Java. These challenges make the business performance of batik SMEs not optimal. On the other hand, these challenges have spurred creativity and open innovation in the Indonesian batik business. The first open innovation is the creation of batik motifs. Several SMEs continue to seek new motifs to attract consumers to purchase batik actively. They use plant, animal, panorama, and local culture as inspiration for their product motifs. These efforts are starting to show positive results. In the West Nusa Tenggara Province, batik was initially unattractive to consumers because it could not compete with the Sasak woven fabrics. However, because of the hard work of SMEs to introduce batik using West Nusa Tenggara cultural motifs, batik is now becoming popular in this region.

"... People used to be unfamiliar with batik and favored Sasak woven fabrics, but that is changing now. Through using local cultural motifs, I was able to introduce batik to the community ... " (Lalu Darmawan, Bumi Gora Batik SME, Mataram City, West Nusa Tenggara Province)

Meanwhile, batik SMEs in Bangka Belitung Province use a local fabric motif, Cual, as a motif. This is done to pique the interest of locals in purchasing batik produced by SMEs in Bangka Belitung. Whereas in Java, specific batik motifs were originally being owned by the royal family. However, this batik motif has spread in society and is commonly used by many people. According to Jalil and Shaharuddin [76], such a move successfully introduced a new product and changed one's behavior, particularly in the fashion industry.

One of Madurese batik SMEs could sell its product at a higher price than similar products because it continued to make innovative motifs. In an economic situation, products like this are known as "luxury goods." They differ from necessary or ordinary goods, so it's normal when the price is higher [77]. These SMEs use the internet to find the latest motifs and fashion trends from around the world. The search results are then used as a motif for 
its batik. These SMEs also use a computer to create batik motifs, which are then printed on large drawing paper. Then the workers will use the motif as a design on the batik fabric. This is very different from the Madurese batik SMEs are known to be conservative to preserve traditional motifs [78]. According to Jyoti and Grover [79], this kind of process plays a vital role in facilitating new designs and improving existing designs in the fashion craft industry. This should inspire batik SMEs to continue innovating motif. Even the Datulaya and Mandalika batik motifs from Banten have received patents and have been declared the best batik motifs in the world based on studies from several countries.

"... With modern motifs, we can sell batik for IDR 5 million per pair. Meanwhile, since the motif is conventional, SMEs in our area can only sell batik for IDR 350 thousand ..." (Didik, Canting Koneng Batik SME, Sumenep Regency, Madura Island, East Java Province)

The second open innovation conducted by SMEs is the use of natural dyes in the batikmaking process. This is done because the price of chemical dyes continues to rise. This step is appropriate because natural dyes have been shown to reduce batik production costs. This is also in line with the research of Peiris et al. [80] argue that the use of coloring technologies will improve business performance and the existence of traditional textile crafts.

Some examples of natural dyes used by SMEs batik include Mahogany (Swietenia mahagoni) wood is used to produce brown color, Tegeran (Cudrania javanensis Trécul) wood is used to produce yellow color, Indigofera (Indigofera tinctoria) leaves to produce blue, Mango (Mangifera indica) wood can produce green color, Rambutan (Nephelium lappaceum) skin produces a creamy color, and Mangosteen (Garcinia mangostana) peel produces a brown color. There is also a superior West Sumatran batik, Tanah Liek batik, using clay as a coloring material. Natural dyes have the advantages of being environmentally friendly and costeffective in the fashion industry as well as ensuring a sustainable business model [36,81].

The use of natural dyes can also pique the attention of workers. Batik with natural dyes is more expensive and sells quicker. As a result, employee wages will be higher and receive prompt payment [64]. The remaining waste can also be reused for the batik coloring process. However, natural dyes also have drawbacks, namely that their use will make the batik-making process longer. This is due to the coloring process that must be done repeatedly to make good-looking batik.

Next, open innovation carried out by batik SMEs in Indonesia is related to improve employee quality. This is very necessary for improving the performance of batik SMEs. Moreover, the employee in the craft industry requires special skills [30]. Many batik trainings are conducted both by SMEs and the local government office. For example, the Aceh provincial government agency conducted batik training in 2006 or 2 years after the tsunami. Today, some of the training participants have been able to sell their batik massively.

Moreover, during rapid technological change, many workers need to develop their skills [82]. Meanwhile, the Jambi provincial government agency held batik training for people aged 18-35 years. This is an effort to regenerate the craft industry in this region. Apart from training, several local government offices also provided housing and equipment for batik production and capital [83]. Government intervention like this is required for the revival of the traditional craft industry [84]. Various training and technology can be beneficial for business development [85].

There are also batik SMEs outside of Java that recruit Javanese employees. Since Java is the center of the Indonesian batik industry, these workers are already well-versed in the development of batik motifs. This approach has proven to improve the performance of batik SMEs and consumer interest in buying batik outside of Java. Even, it can be used to expand into international markets [86].

Batik SMEs also have social open innovation, which is a community-based business. Production centers are located in places close to the batik maker house or the workers given the flexibility to work from home. This is one of the characteristics of Asian business, which is always more community-oriented than individualistic [87]. Community-based 
entrepreneurship has been shown to support sustainability-oriented business innovation in the craft industry [34].

Finally, open innovation is carried out in marketing, both offline and online. Offline marketing activities are carried out through batik exhibitions and fashion shows at local, national, and international levels. This will increase innovation, competitive advantage, and business performance of craft SMEs $[5,61,88]$. The local government is primarily in charge of organizing this event. However, SMEs have connections with other parties and are willing to hold this event.

Several Indonesian batik SMEs have taken part in international exhibitions such as Hamburg Market (Germany), North Sulawesi Expo Netherlands, Minahasa Traditional Culture (Italy), Hong Kong Fashion Week, Batik Transformation (Myanmar), The ASEAN Fest 2016 (the United States), Batik Fashion Show (Philippines), and The Beauty of North Sulawesi (Serbia). These various events have succeeded in increasing the share of Indonesian batik exports.

In Bali and the Special Region of Yogyakarta Provinces, batik SMEs collaborate with the travel agent. Batik SMEs were able to take advantage of the opportunities provided by the economic environment [70]. This turned out to be effective in increasing sales of SMEs batik since the region is a popular tourist destination. They also collaborate with gift shops in several tourist spots. It also demonstrates that craft can be a significant identity and a vital element of the local economy in a region $[63,89]$. Another innovation in offline marketing is a government initiative in several provinces to require employees and students to wear batik one day per week.

Online marketing is also actively carried out by batik SMEs. They promote their products through social media and e-commerce [88]. This has proven to increase batik sales and reach consumers who live a long distance away from SMEs. This is also an adaptation of SMEs to new preferences of consumers who tend to obtain information through digital media [90,91]. Moreover, Indonesia is currently dominated by young people. At this age, people should be interested in using digital media [37]. However, digital media in the craft industry must be handled carefully because it opens up opportunities for "stealing" motifs that are the property of SMEs [92].

"... we do have a website that we use to market and sell our products. We also sell not only batik cloth but also batik products in finished form. We do this to expand our market share." (Bintang Mira Batik SME, Denpasar City, Bali Province)

\subsection{Open Innovation for Helping Batik SMEs and Others Craft SMEs in Indonesia or Around the World}

Open innovation is successful in promoting small businesses. Open innovation can also be used to find professional information and interact with other factors in the business ecosystem. As a result, when open innovation is used to find professional information, SMEs will get product innovation. Meanwhile, as SMEs interact with other factors, they get process and marketing innovation [93]. Wijaya and Suasih [5] argued that the ability of craft SMEs to produce competitive products (in terms of efficiency, quality, uniqueness, price, and flexibility product) would ensure customer satisfaction, raise sales prices and increase market share. Wijaya et al. [12] stated if craft SMEs do not innovate, they will be left behind by their competitors. Yun et al. [94] revealed that competitive products (or new value creation) are created because of open innovation in an industry that links technologies and markets.

Based on our study and research from Budhi et al. [2], open innovation needed by SMEs, among others, relates to product innovation, ease of raw materials, capital, human resources, technology and equipment, and business relationships/networks. This further demonstrates the relationship between open innovation and engagement theory, namely the achievement of open innovation needs participation from all stakeholders. Otherwise, the participation of all stakeholders requires open innovation facilitation. 
If the relationship and interaction between open innovation and participation work well in an industry, it forms open innovation dynamics. This starts with the emergence of a new combination or innovation by craft entrepreneurs or SMEs. Initially, this happened at the micro-level, but it will change the order at the macro level. This can result in a new product or service, a new market, a new process, a new organization, or a new material in the craft industry. Open innovation can also come from intrapreneurship by employees of existing craft firms. With an entrepreneurial spirit, they look for opportunities within existing craft organizations. The results are developing new business areas, accelerating innovation, self-renewal, and proactivity of closed innovation firms to rely on open innovation strategy. The final source of open innovation dynamics is organizational entrepreneurship by the firm itself. This innovation will promote the evolution of the craft industry system. They implement mechanisms for "culture articulation and reinforcement" such as organizational structures, systems, and procedures, as well as formal statements of organizational values, philosophies, or beliefs, to shape the culture for evolutionary transformation in their firms and craft industry $[95,96]$. This is very popular in an industry with different sizes firms. Large firms usually have better performance, outside directors, more considerable pay-performance sensitivity, higher top-management pay levels and others. But, this can always change when different size measures are used [97].

In this study, several SMEs have carried out open innovation (Section 5.2), but there are more batik SMEs that do not implement open innovation, resulting in poor performance of the craft industry. This happened due to a lack of their skills and support from other parties, and the different sizes firms. This situation is consistent with our initial statement in Section 1: open innovation requires engagement theory and vice versa. One concept that shows the combination of the two theories is the Cultivating Forward Neighborhood Rectangular Compass Concept [98].

The first step for craft SMEs is to determine their target market, including existing consumers, and most specifically are new or potential consumers. This concept is following the conditions of the craft industry because consumers are easily bored. As a result, craft SMEs must actively seek out new consumers. Craft SMEs can use digital media to find potential consumers. Therefore, SMEs require counseling and training on adopting and implementing the appropriate technologies in their business. These skills are also needed in the process, product, and marketing innovation and business management [39]. Craft SMEs also require education about waste management and an assessment of their environmental effects. This is necessary to achieve more sustainable environmental management [65]. Aside from that, SMEs must participate in a variety of exhibits at the national and international levels.

Second, make changes in the supply chain to replace existing products or services. Craft SMEs need to keep innovating product redesign to create an entirely new product or motif and diversification [99]. This is to be in tune with the requirements of the contemporary fashion market [34]. Even craft SMEs need to involve customers in the design and production processes and expand the firm's network [100]. There is a successful example of a Japanese heritage craft SMEs in Kyoto. They modify products in the context of international expansion. They hire foreign designers to ensure their products are acceptable to consumers in other countries. However, these SMEs still incorporate elements of Japanese culture as a trademark of their business. This is also for linking systems of local and foreign cultural practices and meanings [41].

Finally, this will develop the addictive consumption of interest [94]. It is also intended to demonstrate consumer participation in engagement theory to provide suggestions for developing the craft industry. In our study, there are several batik SMEs that continue to develop innovative motifs and provide the best service to customers. For example, SMEs on Madura Island use modern batik motifs to attract customer interest. Even, they have used digital technology to find and create batik motifs. These SMEs are also able to sell products at a higher price than conventional batik motifs. Pratiwi et al. [88] also exemplify Sragen batik, which is popular among consumers due to its ability to combine 
traditional and modern motifs. This is also in line with Bonfanti et al. [100], who stated that mixing traditional and digital knowledge will allow craft entrepreneurs to look to the future positively.

Craft SMEs must also establish partnerships with raw material suppliers and financial institutions to ensure their supply chain can be continuous. Most craft SMEs are small firms with financial constraints, limited access to external funding, and a greater risk of bankruptcy [97]. And don't forget about the importance of developing partnerships with employees. According to the findings of this study, employees are comfortable when working from home. This is a social open innovation and fosters good relationships between SMEs and their employees. However, such a system must be adapted to the specific circumstances of each region. This system is not sure to be suitable in other areas and may cause a decrease in employee productivity.

Third, a technology system that is user-centered and promotes collaboration with others in the value chain. Craft SMEs should actively adopt the latest technology and work collaboratively with the craft industry participants [71]. Yun et al. [94] argued that technology would help consumers grasp problems related to products or services. For example, natural dye as a raw material may be used to substitute chemical dyes. These can be found in the surrounding area and commonly thought to be low-cost, non-toxic, renewable, and environmentally friendly resources [62]. Many batik SMEs' managers are unaware of the source of natural dyes in their environment [67].

Nowadays, consumers also propose creative solutions for any problems. They will present their solutions and develop media to deliver the relevant solutions to other consumers. This encourages SMEs to always close to the consumers and asks for suggestions from consumers. This behavior has been shown by some batik SMEs in our study. They have started selling batik through e-commerce in response to the consumers' requests who do not want to visit the batik SMEs store. Meanwhile, business collaboration and networking will improve SMEs' opportunities to succeed in the market $[40,101]$. According to Corte et al. [14], it was easier to begin encouraging collaboration and joint marketing activities among craft SMEs that were not directly competitive.

It should be noted that technology in the craft industry is used to simplify the production process [83]. The handicraft industry creates "unique" products that are hand-made and "full of art". Therefore, the government must immediately address the emergence of the batik printing business, causing unfair competition in the craft industry.

Fourth, craft SMEs must focus on pursuing costs and revenues that are more economical and compatible. This is illustrated in our study, where many SMEs use natural dyes to minimize production costs. Fifth, craft SMEs must focus on business model innovation to find new customers by separating search, purchase, and use. Another critical aspect is that craft SMEs must build partner commitment to mitigate market uncertainty [45].

The various concepts must also be combined with sound understanding from the government to issue policies, provide incentives, and improve the quality of human resources according to the company's characteristics and its managers [102]. This will be useful for managers to shape the organizational structure, salaries, corporate finance, market leverage, and other essential aspects of the firms [103]. If this is successful, stakeholder's participation in the industry will increase, and they will be able to advance sustainable open innovation and good market performance.

Table 3 summarizes the specific innovations or technologies adopted to improve batik SMEs performance in Indonesia. 
Table 3. Summarizes the specific innovations or technologies that could be adopted to improve batik SMEs performance.

\begin{tabular}{cll}
\hline Subsystem & \multicolumn{1}{c}{ Type of Innovations or Technologies } \\
\hline \multirow{3}{*}{ Production } & 1. & Create a completely new product or motif and diversification \\
& 2. & Use natural dyes \\
& 4. & Establish partnerships with raw material suppliers \\
& 5se modern tools without losing the "uniqueness" and "art" of & batik to create products and motifs \\
& 5. & Continuous HR training \\
\hline \multirow{2}{*}{ Marketing } & 2. & Use digital media and e-commerce \\
& 3. & Pevelop communication patterns with consumers \\
& 4. & Cooperate with exporters \\
& 5. & Categorize the batik printing as not a craft \\
\hline \multirow{2}{*}{ Supporting } & 1. & Cooperate with financial institutions \\
& 2. & Develop an online national database system \\
\hline
\end{tabular}

\section{Conclusions}

\subsection{Conclusions}

This study found batik SMEs face many challenges in the production, marketing, and supporting (finance) subsystems. Batik SMEs in Java face challenges in the form of increasing raw material prices, low quality of employee skills, slow regeneration, poor waste management, increased competition with the batik printing business, inability to do online marketing, and lack of capital. Meanwhile, batik SMEs outside of Java face challenges, difficulty obtaining raw materials, low quality of employee skills, slow regeneration, competition with the batik printing and local fabrics business, inability to do online marketing, capital constraints, and an incomplete profile database of batik SMEs.

Some batik SMEs in Java and outside of Java have carried out open innovation, such as creating new motifs or designs, using natural dyes, improving the quality of human resources, implementing social business management, and conducting online \& offline marketing. Open innovation has been shown to improve their business performance. This is driven by managers' skill and creativity in responding to customer needs and other stakeholders' encouragement. However, this is not the case for most batik SMEs in Indonesia, resulting in their performance not optimal. They are hampered by the reluctance of managers to innovate and respond to changing markets, lack of employee skills and other resource limitations. This is exacerbated by the lack of supplier and government support for batik SMEs.

\subsection{Implications}

We suggest that there is an increase in the participation of stakeholders in the craft industry. This is consistent with our expectation that engagement theory will increase open innovation in numerous businesses, especially the craft industry. Stakeholders need to provide training for batik SMEs such as manager skill-building and enthusiasm for innovation. In the business world, this is known as the Cultivating Forward Neighborhood Rectangular Compass Concept [83]. We add to the open innovation researchers' perspective that there is a high possibility for its development to be combined with other theories. As a result, making open innovation will be more dynamic, effective, and adaptive in various types of businesses and conditions.

We also encourage each actor to partake in open innovation at all times. This will increase stakeholder participation because open innovation will facilitate business activities in the craft industry. However, it all needs: (1) a clear strategy that involves all craft industry members as well as internal experts; (2) a concentration on the value chain and consumer-centric innovation; (3) a visionary leader who proposes solutions to different challenges, encourages cultural change, and creates tools or smart apps to support co- 
innovation; (4) a measure of innovation capability (qualitative, quantitative, baseline) that should be related to key performance indicators, reward mechanisms, and benchmarking; (5) support for all stakeholders in innovation development and reward or compensation; and (6) academics to teach system reform and increase student participation, industry role, and social responsibility [104].

\subsection{Limitations}

The most significant barrier in this study is the large region of Indonesia with various geographical conditions. Moreover, the number of batik SMEs in Indonesia is so large that we cannot reach all batik SMEs. This may make our study not completely capable of having a whole perspective on the various challenges faced by batik SMEs, especially in remote areas. Another limitation is that we only see open innovation from the perspective of SMEs. Even though this is not necessarily correct because consumer preferences can change very quickly. So open innovation conducted by SMEs may fail to meet consumer expectations.

\subsection{Future Research}

First, we recommend that further studies be undertaken to collaborate with researchers in each province in Indonesia. They will be able to help to map the condition of batik SMEs in each province. Second, we recommend that further research focus on the behavior of batik (or other crafts) consumers. This is intended to give a perspective for batik (or other crafts) SMEs on marketing strategies to satisfy consumers. Third, there are needs to be a study focusing on competition between batik (or other crafts) SMEs with the batik printing business (or other crafts firms) and policy recommendations to create a fair-trade system. This ensures that technology is used to help the craft industry's business processes rather than eliminate handcrafted art from the industry. Finally, we hope the combination of open innovation and engagement theory can be used for research in several other fields.

Author Contributions: Conceptualization, A.B.R. and A.D.N.; methodology, A.B.R. and A.D.N.; software, A.D.N.; validation, R.A., A.P.S. and I.Y.P.; formal analysis, A.D.N.; investigation, I.Y.P., F.I., T.G.Y.S. and A.T.K.; resources, A.B.R. and A.D.N.; data curation, T.G.Y.S. and A.T.K.; writingoriginal draft preparation, A.B.R., R.A., A.P.S., I.Y.P. and A.D.N.; writing-review and editing, A.D.N.; visualization, A.D.N.; supervision, A.B.R. and A.D.N.; project administration, F.I. All authors have read and agreed to the published version of the manuscript.

Funding: This study funded by the Indonesian Ministry of Industry (Project Agreement Number 971/IKMA.3/XI/2019 about Compilation of Data on Batik SMEs in Indonesia).

Data Availability Statement: The data presented in this study are available on request from the corresponding author.

Acknowledgments: We would like to thank, first, the reviewers who gave us suggestions on how to develop this article. Secondly, the Indonesian Ministry of Industry who gave fund for this study. Last, to the local government officers and managers of batik SMEs, who allowed collecting data.

Conflicts of Interest: The authors declare no conflict of interest.

\section{References}

1. Ardic, O.P.; Mylenko, N.; Saltane, V. Small and Medium Enterprises: A Cross-Country Analysis with a New Data Set; The World Bank: Washington, DC, USA, 2011; pp. 21-23.

2. Budhi, M.K.S.; Lestari, N.P.N.E.; Suasih, N.N.R.; Wijaya, P.Y. Strategies and Policies for Developing SMEs Based on Creative Economy. Manag. Sci. Lett. 2020, 10, 2301-2310. [CrossRef]

3. The Indonesian Ministry of Cooperative and SMEs. Number of SMEs in Indonesia. Available online: http://umkm.depkop.go.id/ (accessed on 14 March 2021).

4. Panjaitan, J.M.; Timur, R.P.; Sumiyana, S. How Does the Government of Indonesia Empower SMEs? An Analysis of the Social Cognition Found in Newspapers. J. Entrep. Emerg. Econ. 2020, in press. [CrossRef]

5. Wijaya, P.Y.; Suasih, N.N.R. The Effect of Knowledge Management on Competitive Advantage and Business Performance: A Study of Silver Craft SMEs. Entrpreneurial Bus. Econ. Rev. 2020, 8, 105-121. [CrossRef] 
6. Director General of National Export Developmen. Efforts to Introduce Batik in the International Arena; The Indonesian Ministry of Trade: Jakarta, Indonesia, 2012; pp. 3-13.

7. Cultural Selection: “Batik for the World” Exhibiton at UNESCO. Available online: https://en.unesco.org/silkroad/content/ cultural-selection-batik-world-exhibition-unesco (accessed on 14 March 2021).

8. Iriyanto, S.; Suharmono; Hidayat, M.T.; Anas, M. Do Intangible Assets and Innovation Orientation Influence Competitive Advantages? A Case Study of SMEs in Indonesia. Univers. J. Account. Financ. 2021, 9, 105-115. [CrossRef]

9. Deltour, F.; Le Gall, S.; Lethiais, V. Partners and Geographical Scale of SMES' Open Innovation: Does Business Group Affiliation Matter? Int. J. Innov. Manag. 2021, in press. [CrossRef]

10. Yun, J.J.; Won, D.; Park, K. Dynamics from Open Innovation to Evolutionary Change. J. Open Innov. Technol. Mark. Complex. 2016, 2, 7. [CrossRef]

11. Chesbrough, H.W. Open Innovation: The New Imperative for Creating and Profiting from Technology; Harvard Business Press: Boston, MA, USA, 2003; pp. 43-112.

12. Wijaya, P.Y.; Rahyuda, I.K.; Yasa, N.N.K.; Sukaatmadja, I.P.G. Dilemma of Innovation in Silver Craft SMEs in Gianyar Regency of Bali Province, Indonesia. Espacios 2019, 22, 15-22.

13. De Marco, C.E.; Martelli, I.; Di Minin, A. European SMEs' Engagement in Open Innovation When the Important Thing is to Win and Not Just to Participate, What Should Innovation Policy Do? Technol. Forecast. Soc. Chang. 2020, 152, 119843. [CrossRef]

14. Kearsley, G.; Shneiderman, B. Engagement Theory: A Framework for Technology-Based Teaching and Learning. Educ. Technol. 1998, 38, 20-23.

15. West, J.; Salter, A.; Vanhaverbeke, W.; Chesbrough, H. Open Innovation: The Next Decade. Res. Policy 2014, 43, 805-811. [CrossRef]

16. Hardwick, J.; Anderson, A.R. Supplier-customer engagement for collaborative innovation using video conferencing: A study of SMEs. Ind. Mark. Manag. 2019, 80, 43-57. [CrossRef]

17. Zainal, N.T.A.; Yong, K. Engaging Travellers in the Context of Tourism SMEs: A Conceptual Paper. Int. J. Adv. Sci. Technol. 2020, 29, 1544-1549.

18. Grama-Vigouroux, S.; Saidi, S.; Berthinier-Poncet, A.; Vanhaverbeke, W.; Madanamoothoo, A. From Closed to Open: A Comparative Stakeholder Approach for Developing Open Innovation Activities in SMEs. J. Bus. Res. 2020, 119, $230-244$. [CrossRef]

19. Veronica, S.; Alexeis, G.-P.; Valentina, C.; Elisa, G. Do Stakeholder Capabilities Promote Sustainable Business Innovation in Small and Medium-sized Enterprises? Evidence from Italy. J. Bus. Res. 2020, 119, 131-141. [CrossRef]

20. Fauth, J.; Marquardt, C.; Di Bari, G.; Raule, N.; Ronco, J.L.; Scholz, S.G. Stakeholder-driven Conceptualization of Open Innovation Approaches in the Synergy Project. Smart Innov. Syst. Technol. 2021, 200, 307-317. [CrossRef]

21. Mawson, S.; Brown, R. Entrepreneurial Acquisitions, Open Innovation and UK High Growth SMEs. Ind. Innov. 2017, $24,382-402$. [CrossRef]

22. Jonsson, L.; Baraldi, E.; Larsson, L.-E.; Forsberg, P.; Severinsson, K. Targeting Academic Engagement in Open Innovation: Tools, Effects and Challenges for University Management. J. Knowl. Econ. 2019, 6, 522-550. [CrossRef]

23. Barrett, G.; Dooley, L. Open Innovation Strategy of an Early-Stage SME. Contrib. Manag. Sci. 2021, 85-99. [CrossRef]

24. Andalib, T.W.; Halim, H.A. Convergence of Conceptual Innovation Model to Reduce Challenges Faced by the Small and Medium Sized Enterprises (SMEs) in Bangladesh. J. Open Innov. Technol. Mark. Complex. 2019, 5, 63. [CrossRef]

25. Foltys, J.; Dębicka-Ozorkiewicz, G.; Królczyk, J.B.; Hiadlovský, V. Financing Craft Enterprises Association in the Polish Craft Association. Ekon. Manag. 2015, 18, 166-183. [CrossRef]

26. Corte, V.D.; Zamparelli, G.; Micera, R. Innovation in Tradition-based Firms: Dynamic Knowledge for International Competitiveness. Eur. J. Innov. Manag. 2013, 16, 405-439. [CrossRef]

27. Kurniati, E.D.; Susilowati, I.; Suharno. Sustainable Competitive Advantage of SMEs through Resource and Institutional-Based Management: An Empirical Study of Batik SMEs in Central Java, Indonesia. Trz. Mark. 2019, 31, 61-82. [CrossRef]

28. Agyapong, D. Analyzing Financial Risks in Small and Medium Enterprises: Evidence from the Food Processing Firms in Selected Cities in Ghana. Int. J. Entrep. Behav. Res. 2020, 22, 45-77. [CrossRef]

29. Sukartini, N.W.; Kencanawati, A.A.A.M.; Lasmini, N.K. Business Performance and Competitive Advantage: Multi Perspective Analysis of SMEs in Bali. Int. J. Manag. 2019, 10, 105-113. [CrossRef]

30. Roostika, R.; Wahyuningsih, T.; Haryono, S. The Impacts of External Competitiveness Factors in the Handicrafts Industry. Pol. J. Manag. Stud. 2015, 12, 166-176.

31. Putri, C.F.; Nugroho, I.; Purnomo, D. Performance Measurement of SMEs of Malang Batik as a Result of Local Wisdom with Balanced Scorecard. In Proceedings of the 1st International Conference on Industrial and Manufacturing Engineering, Medan, Indonesia, 16-17 October 2018; Ishak, A., Ed.; University of Sumatera Utara: Medan, Indonesia, 2019.

32. Anderson, W.; Komba, I.M. Female Entrepreneurs and Poverty Reduction: Hair Craft SMEs in Tanzania. Dev. Pract. 2017, 27, 392-407. [CrossRef]

33. Lita, R.P.; Faisal, R.F.; Meuthia, M. Enhancing Small and Medium Enterprises Performance through Innovation in Indonesia: A Framework for Creative Industries Supporting Tourism. J. Hosp. Tour. Technol. 2020, 11, 155-176. [CrossRef]

34. Wanniarachchi, T.; Dissanayake, K.; Downs, C. Improving Sustainability and Encouraging Innovation in Traditional Craft Sectors: The Case of the Sri Lankan Handloom Industry. Res. J. Text. Appar. 2020, 24, 111-130. [CrossRef] 
35. Wahyuni, D.; Sinaga, L.T.; Budiman, I. Human Error Assessment in Batik Enterprises Located in North Sumatera Using HEART Method. In Proceedings of the 2nd Talenta Conference on Engineering, Science and Technology, Medan, Indonesia, 17 October 2019; Faculty of Engineering University of Sumatera Utara: Medan, Indonesia, 2020.

36. Alonso, D.A.; Bressan, A.; Sakellarios, N. Exploring Innovation Perceptions and Practices among Micro and Small Craft Breweries: A Threecountry Study. Int. J. Wine Bus. Res. 2017, 29, 140-158. [CrossRef]

37. Seifert, A.; Cotton, S.R. In Care and Digitally Savvy? Modern ICT Use in Long-term Care Institutions. Educ. Gerontol. 2020, 46, 473-485. [CrossRef]

38. Dirgiatmo, Y.; Abdullah, Z.; Mohd Ali, R.H.R. Social media practices in Indonesian SMEs. Int. J. Bus. Inf. Syst. 2020, 35, 3-26. [CrossRef]

39. Hendayana, Y.; Suryana.; Ahman, E.; Mulyadi, H. Do Technological Capabilities Influence Innovation in Creative Industry: The Case of Handicraft Sector in Indonesia. Int. J. Sci. Technol. Res. 2019, 8, 1722-1725.

40. Prasanna, R.P.I.R.; Jayasundara, J.M.S.B.; Gamage, S.K.N.; Ekanayake, E.M.S.; Rajapakshe, P.S.K.; Abeyarathne, G.A.K.N.J. Sustainability of SMEs in the Competition: A Systemic Review on Technological Challenges and SME Performance. J. Open Innov. Technol. Mark. Complex. 2019, 5, 100. [CrossRef]

41. Sasaki, I.; Nummela, N.; Ravasi, D. Managing Cultural Specificity and Cultural Embeddedness when Internationalizing: Cultural Strategies of Japanese Craft Firms. J. Int. Bus. Stud. 2021, 52, 245-281. [CrossRef]

42. Ness, B. Beyond the Pale (Ale): An Exploration of the Sustainability Priorities and Innovative Measures in the Craft Beer Sector. Sustainability 2018, 10, 4108. [CrossRef]

43. Yun, J.J.; Park, Y.; Gaudio, G.D.; Corte, V.D. Open Innovation Ecosystems of Restaurants: Geographical Economics of Successful Restaurants from Three Cities. Eur. Plan. Stud. 2020, 28, 2348-2367. [CrossRef]

44. Maulana, L.H.; Ch, I.; Gemina, D. Cultural Tourism Marketing for SMEs Empowerment. Int. J. Sci. Technol. Res. 2019, 8, 3503-3508.

45. Kubberod, E.; Viciunaite, V.; Fosstenløkken, S.M. The Role of Effectual Networking in Small Business Marketing. J. Small Bus. Enterp. Dev. 2019, 26, 747-763. [CrossRef]

46. Ali, F.H.; Ali, M.; Malik, S.Z.; Hamza, M.A.; Ali, H.F. Managers' Open Innovation and Business Performance in SMEs: A Moderated Mediation Model of Job Crafting and Gender. J. Open Innov. Technol. Mark. Complex. 2020, 6, 89. [CrossRef]

47. Srisathan, W.A.; Ketkaew, C.; Naruetharadhol, P. The Intervention of Organizational Sustainability in the Effect of Organizational Culture on Open Innovation Performance: A Case of Thai and Chinese SMEs. Cogent Bus. Manag. 2020, 7, 1717408. [CrossRef]

48. Yun, J.J.; Park, K.; Kim, J.; Yang, J. Open Innovation Effort, Entrepreneurship Orientation and their Synergies onto Innovation Performance in SMEs of Korea. Sci. Technol. Soc. 2016, 21, 366-390. [CrossRef]

49. Cardoni, A.; Dumay, J.; Palmaccio, M.; Celenza, D. Knowledge Transfer in A Start-up Craft Brewery. Bus. Process. Manag. J. 2018, 25, 219-243. [CrossRef]

50. Freeman, R.E. Stakeholder Theory of the Modern Corporation. In General Issues in Business Ethics; University of Toronto Press: Toronto, ON, Canada, 1998; pp. 38-48.

51. The Indonesian Ministry of Industry. List of Batik and Handicraft Industry Companies. 2021. Available online: https://www. batik.go.id/index.php/post/read/daftar_perusahaan_industri_kerajinan_dan_batik_0 (accessed on 20 March 2021).

52. Wahyuningsih, T.; Bugis, M.; Bin-Tahir, S.Z. Analysis of the Inequality on Inter-regional and Inter-time Income Distribution in Indonesia. J. Soc. Sci. Res. 2019, 5, 1-8. [CrossRef]

53. Hair, J.R.J.; Black, W.C.; Babin, B.J.; Anderson, R.E. Multivariate Data Analysis; Pearson Education Limited: Harlow, UK, 2014; pp. 99-115.

54. Kothari, C.R. Research Methodology Methods and Techniques, 2nd ed.; New Age International Publishers: New Delhi, India, 2004; pp. $2-33$.

55. Sekaran, U. Research Methods for Business: A Skill-Building Approach, 4th ed.; John Wiley and Sons: New York, NY, USA, 2003; pp. 121-123.

56. Pandey, P.; Pandey, M.M. Research Methodology: Tools and Techniques; Bridge Center: Buzau, Romania, $2015 ;$ pp. 7-9.

57. Loeb, S.; Dynarski, S.; McFarland, D.; Morris, P.; Reardon, S.; Reber, S. Descriptive Analysis in Education: A Guide for Researchers; Department of Education, Institute of Education Sciences, National Center for Education Evaluation and Regional Assistance: Washington, DC, USA, 2017; pp. 1-7.

58. Kielmann, K.; Cataldo, F.; Seeley, J. Introduction to Qualitative Research Methodology: A Training Manual; Department for International Development: London, UK, 2012; pp. 67-75.

59. Szilvia, V. Research Methodology; University of Debrecen: Debrecen, Hungary, 2013; pp. 18-28.

60. Degu, G.; Yigzaw, T. Research Methodology; University of Gondar: Addis Ababa, Ethiopia, 2006; pp. 25-27.

61. Fauzi, R.H.; Liquiddanu, E.; Suletra, I.W. Improving Competitiveness of Small Medium Batik Printing Industry on Quality and Productivity Using Value Chain Benchmarking (Case study SME X, SME Y and SME Z). In Proceedings of the 3rd International Conference on Industrial, Mechanical, Electricity, and Chemical Engineering, Surakarta, Indonesia, 13-14 September 2017; Nur, A., Wijayanta, A.T., Budiman, A.W., Eds.; Sebelas Maret University: Surakarta, Indonesia, 2018.

62. Fauzi, A.M.; Defianisa, R.L. Analysis for Cleaner Production Implementation Strategy in Batik Industry in Bogor. In Proceedings of the International Symposium on Transdisciplinary Approach for Knowledge Co-Creation in Sustainability 2018, Bogor, Indonesia, 6 November 2018; Alatas, H., Buchori, D., Zamani, N.P., Eds.; IPB University: Bogor, Indonesia, 2019. 
63. Adawiyah, W.R.; Praptapa, A.; Dian, P.; Kusuma, I.; Sholikhah, Z. Promoting Local Potential as a Strategy to Develop Tourism Village. Geoj. Tour. Geosites 2020, 31, 1113-1118. [CrossRef]

64. Borshalina, T. Marketing Strategy and the Development of Batik Trusmi in the Regency of Cirebon which Used Natural Coloring Matters. In Proceedings of the 6th Indonesia International Conference on Innovation, Entrepreneurship and Small Business, Bali, Indonesia, 12-14 August 2014; Bandung Institute of Technology: Bandung, Indonesia, 2015.

65. Handayani, W.; Kristijanto, A.A.; Hunga, A.I.R. Are Natural Dyes Eco-friendly? A Case Study on Water Usage and Wastewater Characteristics of Batik Production by Natural Dyes Application. Sustain. Water Resour. Manag. 2018, 4, 1011-1021. [CrossRef]

66. Jamaludin, M.Z. Study on Removal of Pollutant from Batik Wastewater Using Coal Bottomash (CBA). In Proceedings of the 2nd International Conference on Civil and Environmental Engineering, Kedah, Malaysia, 20-21 November 2019; University Malaysia Perlis: Perlis, Malaysia, 2020.

67. Sebayang, L.K.B.; Utami, S.; Suseno, D.A. Will Natural-dying Batik SMEs Compete in Asian Economic Community? J. Soc. Sci. Res. 2019, 5, 343-347. [CrossRef]

68. Widyantoko, Z.; Widowati, T.P.; Isnaini, I.; Trapsiladi, P. Expert Role in Image Classification Using cnn for Hard to Identify Object: Distinguishing Batik and its Imitation. IAES Int. J. Artif. Intell. 2021, 10, 93-100. [CrossRef]

69. Novianti, T. Virtual Enterprise for Batik's Small Medium Enterprises. J. Phys. Conf. Ser. 2020, 1569, 032024. [CrossRef]

70. Papanek, G.F. The Pribumi Entrepereneurs of Bali and Central Java (or How Not to Help Indigenous Enterprise). Bull. Indones. Econ. Stud. 2006, 42, 79-93. [CrossRef]

71. Rahab; Anwar, N.; Priyono, E.R. Sustainable Development of Batik Banyumas as Creative Industry: A-B-G Community-Based Triple Helix Model. Int. Bus. Manag. 2016, 10, 446-450. [CrossRef]

72. Firdausya, A.R.; Umamah, N. Situbondo Batik: Natural Resource in Culture. In Proceedings of the First International Conference on Environmental Geography and Geography Education (ICEGE), Jember, Indonesia, 17 November 2018; Sumardi, Ed.; Faculty of Teacher Training and Education University of Jember: Jember, Indonesia, 2019.

73. Nuraedaha; Bakri, M.; Kasim, A.A. Quadratic Support Vector Machine for the Bomba Traditional Textile Motif Classification. Indones. J. Electr. Eng. Comput. Sci. 2018, 11, 1004-1014. [CrossRef]

74. Setyaning, K.A.; Nugroho, P. The Role of Batik and Lurik in Forming Local Identity in Klaten Regency Based on Public Perception. J. Reg. City Plan. 2017, 28, 32-51. [CrossRef]

75. Eisingerich, A.; Chun, H.; Liu, Y.; Jia, H.; Bell, S. Why Recommend a Brand Face-to-Face but Not on Facebook? How Word-of Mouth on Online Social Sites Differs from Traditional Word-of-Mouth. J. Consum. Psychol. 2015, 25, 120-128. [CrossRef]

76. Jalil, M.H.; Shaharuddin, S.S. Fashion Designer Behavior Toward Eco-Fashion Design. J. Vis. Art Des. 2020, 12, 1-24. [CrossRef]

77. Savelli, E. Role of Brand Management of the Luxury Fashion Brand in the Global Economic Crisis: A Case Study of Aeffe Group. J. Glob. Fash. Mark. 2011, 2, 170-179. [CrossRef]

78. Kusuma, P.D. Modified Sine Wave Based Model in Madurese Batik Pattern Generation. J. Theor. Appl. Inf. Technol. 2019, 97, 3557-3569.

79. Jyoti, G.E.; Grover, M.E. Designing and Printing of Bed Cover Using CAD Technology. Text. Trends 2009, 52, 29-32.

80. Peiris, R.L.; Koh, J.T.K.V.; Tharakan, M.J.; Fernando, O.N.N.; Cheok, A.D. AmbiKraf Byobu: Merging Technology with Traditional Craft. Interact. Comput. 2013, 25, 173-182. [CrossRef]

81. Sachan, P.; Wadhwa, A.; Choudhary, S.; Muthusamy, A. Rejuvenation of Traditional Leather Crafts with Innovative Surface Design Interventions-A Case Study Approach. In Proceedings of the 34th IULTCS Congress: Science and Technology for Sustainability of Leather, Chennai, India, 5-8 February 2017; CSIR-CLRI: Chennai, India, 2017.

82. Raphael, L. Knowledge, Skills, Craft? The Skilled Worker in West German Industry and the Resilience of Vocational Training, 1970-2000. Ger. Hist. 2019, 37, 359-373. [CrossRef]

83. Rizana, A.F.; Kurniawati, A.; Samadhi, T.M.A.A.; Wiratmadja, A.A.; Sunaryo, I. Value Chain Analysis for Determining Innovation Priority in Batik Small Medium Industry. In Proceedings of the International Conference on Industrial Engineering and Operations Management, Bandung, Indonesia, 6-8 March 2018; Bandung Institute of Technology: Bandung, Indonesia, 2019.

84. Shafi, M.; Yin, L.; Yuan, Y. Revival of the Traditional Handicraft Enterprising Community in Pakistan. J. Enterprising Communities People Places Glob. Econ. 2020, in press. [CrossRef]

85. Chandna, V.; Salimath, M.S. When Technology Shapes Community in the Cultural and Craft Industries: Understanding Virtual Entrepreneurship in Online Ecosystems. Technovation 2020, 92, 102042. [CrossRef]

86. Kalkreuter, B. Anyone's Heritage? Indian Fashion Design's Relationships with Craft between Local Guardianship and Valorization of Global Fashion. Fash. Pract. 2020, 12, 264-287. [CrossRef]

87. Gunawan, A.A.; Essers, C.; van Riel, A.C.R. The Adoption of Ecopreneurship Practices in Indonesian Craft SMEs: Value-based Motivations and Intersections of Identities. Int. J. Entrep. Behav. Res. 2020, 27, 730-752. [CrossRef]

88. Pratiwi, A.; Riani, A.L.; Harisudin, M.; Sarah, R.H.P. The Development of Market Oriented Batik Products Based on Customer Buying Intention (Industrial Center of Batik Sragen Indonesia). Int. J. Manag. 2020, 11, 373-389. [CrossRef]

89. Koumara-Tsitsou, S.; Karachalis, N. Traditional Products and Crafts as Main Elements in the Effort to Establish a City Brand Linked to Sustainable Tourism: Promoting Silversmithing in Ioannina and Silk Production in Soufli, Greece. Place Brand. Public Dipl. 2021, In press. [CrossRef]

90. Rezabakhsh, B.; Bornemann, D.; Hansen, U.; Schrader, U. Consumer Power: A Comparison of the Old Economy and the Internet Economy. J. Consum. Policy 2006, 29, 3-36. [CrossRef] 
91. Fuentes, C.; Svingstedt, A. Mobile Shopping and the Practice of Shopping: A Study of How Young Adults Use Smartphones to Shop. J. Retail. Consum. Serv. 2017, 38, 137-146. [CrossRef]

92. Bowker, S.; El Rashidi, S. The Street and the Screen: Egyptian Tentmakers and Craft Online. J. Mod. Craft 2020, 13, 51-66. [CrossRef]

93. Harel, R.; Schwartz, D.; Kaufmann, D. Open Innovaton in Small Business in the Industry and Craft Sectors. Int. J. Innov. Manag. 2019, 23, 1950038. [CrossRef]

94. Yun, J.J.; Yang, J.; Park, K. Open Innovation to Business Model: New Perspective to Connect between Technology and Market. Sci. Technol. Soc. 2016, 21, 324-348. [CrossRef]

95. Yun, J.J.; Zhao, X.; Jung, K.; Yigitcanlar, T. The Culture for Open Innovation Dynamics. Sustainability 2020, 12, 5076. [CrossRef]

96. Mintarti, W.S.U.; Soesilo, Y.H.; Putri, R.D.; Rachmawati, D. The Existence of Marble and Onyx Handicrafts in Gamping Village in Improving Community's Welfare. In Proceedings of the First International Research Conference on Economics and Business, Malang, Indonesia, 11-12 December 2017; Faculty of Economics State University of Malang: Malang, Indonesia, 2018.

97. Dang, C.; Li, Z.F.; Yang, C. Measuring Firm Size in Empirical Corporate Finance. J. Bank. Financ. 2018, 86, 159-176. [CrossRef]

98. Yun, J.J.; Zhao, X. Business Model Innovation through a Rectangular Compass: From the Perspective of Open Innovation with Mechanism Design. J. Open Innov. Technol. Mark. Complex. 2020, 6, 131. [CrossRef]

99. Masruro, D.; Wahyuni, S.; Widodo, J.; Sukidin; Zulianto, M. The Strategy of Product Diversification on SMEs Brass Craft in Cindogo Village Bondowoso. In Proceedings of the Second International Conference on Environmental Geography and Geography Education (ICEGE), Jember, Indonesia, 28-29 September 2019; Sumardi, Ed.; Faculty of Teacher Training and Education University of Jember: Jember, Indonesia, 2020.

100. Bonfanti, A.; Giudice, M.D.; Papa, A. Italian Craft Firms Between Digital Manufacturing, Open Innovation, and Servitization. J. Knowl. Econ. 2018, 9, 136-149. [CrossRef]

101. Rosyadi, S.; Kusuma, A.S.; Fitrah, E.; Haryanto, A.; Adawiyah, W. The Multi-Stakeholder's Role in an Integrated Mentoring Model for SMEs in the Creative Economy Sector. SAGE Open 2020, 10, 1-14. [CrossRef]

102. Coles, J.F.; Li, Z.F. Managerial Attributes, Incentives, and Performance. Rev. Corp. Financ. Stud. 2020, 9, 256-301. [CrossRef]

103. Coles, J.F.; Li, Z.F. An Empirical Assessment of Empirical Corporate Finance. SSRN 2019, 7, 1-111. [CrossRef]

104. Traitler, H.; Watzke, H.J.; Saguy, I.S. Reinventing R\&D in an Open Innovation Ecosystem. J. Food Sci. 2011, 76, 62-68. [CrossRef] 